\title{
The role of information technology management in supporting managerial innovation
}

\author{
Fadwa Issa Alsalima ${ }^{\text {* }}$ \\ C H R O N I C L E \\ Article history: \\ Received: February 16, 2020 \\ Received in revised format: \\ March 272020 \\ Accepted: March 29, 2020 \\ Available online: \\ April 1, 2020 \\ Keywords: \\ Information technology \\ Information technology manage- \\ ment \\ Managerial innovation \\ Jordanian \\ E-Government
}

${ }^{a}$ Computer Science Department, Imam Abdulrahman Bin Faisal University, Dammam, Community College, Saudi Arabia \begin{abstract}
A B S T R A C T
Current study aimed at examining the influence of ITMG (Information Technology Management) on Jordanian e-government approaches towards adopting managerial innovation. Through adopting the quantitative approach and utilizing questionnaire as a study tool; the researcher distributed a self-administered questionnaire on (123) head departments, officers and technicians in Jordanian E-government project. Results of study indicated a strong positive relationship between ITMG and managerial innovation that is attributed to business architecture and risk management plans and strategies. Study recommended that e-government controllers must have extra attention towards adopting the suitable Business Process Improvement (BIP) in order to guarantee the best results of application in terms of service quality, time and satisfaction.
\end{abstract}

\section{Introduction}

Information technology (IT) is a broad competence concerned with all aspects of technology, information processing and management, especially in large organizations, through dealing with computer software and electronic computers for the purpose of transfer, storage, protection, processing, transfer and retrieval of information. Information technology emerged in the 1990s when computers became the basic tools of work at all levels and fields to meet the demands of everyday life, business or various practical activities in institutions, as well as with students, so specialists had to develop technology and lay the foundations for its infrastructure (Azam, 2015). It is meant to manage public transactions and services provided to citizens in the state electronically, by using computers instead of using traditional methods such as paper or moving from one department to another (Florkowski, 2018).

\section{Problem Statement}

The idea of information technology within organization is among the aspects that play a significant role in defining and identifying the organizational performance within the framework of technology. With the technological advancements that the world is witnessing today there appeared to be a massive interest in gathering between technology and management in all its activities. From that point there appeared approach and programs that supports the organizational sought to reach managerial excellence in all managerial activities based on technology (Dahiya \& Mathew, 2016). According to Saatçioğlu et al. (2009) technology now supports the managerial department in all its activities including decision making process. It also plays a role in identifying the points of weaknesses which an organization has to develop and points of strength which it needs to preserve and manage. From another perspective; in order to reach technological developments, there has to be a high level of innovation, and in order to get the most out of technology, innovation is also required. This was agreed on by Hassan and Lee (2019) who argued that innovation in management, stream of thinking, approaches and skills is a key pre-requisite in order to * Corresponding author

E-mail address: fialsalim@iau.edu.sa (F. I. Alsalim) 
enjoy the privileges of living among technology. When it comes to public services; it appeared that innovation has a master role in defining and establishing the whole perspective of technology in public service. Electronic government - e-government- appeared to one of the basic items in which technology appears to be supportive to (Zhao et al., 2015). As an approach to manifest the main aim here, Fig. 1 shows the proposed model established combining between dependent and independent variables of study:

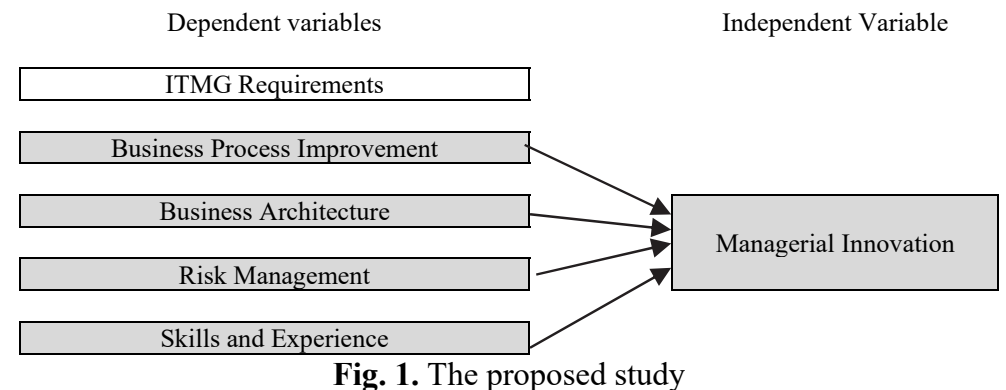

As it can be seen from the above model; researcher hypothesize a relationship that gathers between information technology management and managerial innovation. From that point, the main aim of study appears as to examine the importance of ITMG requirements on managerial innovation in reference to the environment of e-government in Jordan. In tackling the aim of study, researcher was able to develop the following set of hypotheses:

\section{Main Hypothesis:}

ITMG positively influence managerial innovation within e-government project in Jordan

\section{Sub-Hypotheses:}

Business Process Improvement influences managerial innovation within e-government project in Jordan.

Business Architecture influences managerial innovation within e-government project in Jordan.

Risk Management influences managerial innovation within e-government project in Jordan.

Skills and Experiences influence managerial innovation within e-government project in Jordan.

\section{Literature Review}

\subsection{Information Technology Management - ITMG}

Information Technology Management - ITMG - refers to the state of managing the IT infrastructure and resources needed to plan, develop and deliver IT services and products to meet business needs. Prepare for new or changing services, manage the change process, and maintain organizational, legal and professional standards (Al-Athmay et al., 2016). Manage the performance of systems and services in terms of their contribution to business performance, financial costs and sustainability, Purchased Services Department. Develop ongoing service improvement plans to ensure that the IT infrastructure adequately supports business needs (Mousavi \& HabibyBadrAbady, 2008). Melville et al. (2004) stated that the main ore of ITMG is to develop a strategy for managing technology resources, including management communications functions, and enhances the opportunities that technology offers to the operating organization that include the potential for change and potentially impact on the business. It allows allocation of resources for planning, development and delivery of all information systems products and services. Responsibility for IT control. In addition to that, it approves institutional policies governing the management of change initiatives and professional behavior standards. Has an overview of how programs contribute to institutional success, not to mention that it urges innovation and flexibility in IT management and administration and develops a strategy to monitor and manage the performance of IT-related systems and services in terms of their contribution to business performance and the benefits to the business. According to Brynjolfsson and Hitt (2000) ITMG has the ability to identify and manage resources for planning, developing and providing information and services for specific communication systems (including data, voice, text, images) Affects high-level clients and project teams through change management initiatives, to ensure infrastructure management to provide agreed service levels and data integrity. Kane and Alavi (2007) also supported the fact that ITMG is responsible for budgeting, evaluation, planning and goal setting. Plans and manages the application of processes and procedures, tools and methods to monitor and manage the performance of automated systems and services, in terms of their contribution to work performance and the benefits to the work, where measuring success depends on the achievement of business objectives / financial goals and business objectives explicitly stated. Monitors performance and takes corrective action if necessary. On the other hand, Butt et al. (2019) saw that ITMG is normally responsible for design, supply, installation, upgrade, operation, control and maintenance (including data storage and communication, audio, text and images) and effective 
use of IT infrastructure components and monitors their performance. Provides technical management of the IT process and ensures that agreed service levels are met and that all relevant procedures are complied with. Also, Hamidi and Benabdeljlil, (2015) stated that ITMG establishes a schedule for all maintenance and installation and it ensures that all operational problems are identified and resolved, while Swanepoel et al. (2001) ITMG provides a valid status report and other reports for professionals, users, and managers and it ensures that all operational procedures and work practices are appropriate for their purpose and contemporary.

\subsection{Business Process Improvement}

The idea of business process improvement BPI refers to all methodologies, approaches, techniques and activities that managers adopt in an organization in order to develop the end results of internal activities in an organization. According to Adesola and Baines (2005) the first step towards achieving BPI is to identify the activity in an organization and connect it to the right employee with the right skills, this step as according to Zellner (2011) would draw the attention towards the developments and enhancements that needs to be done on employees and launch training, courses and workshops in order to develop their performance. Siha and Saad (2008) saw that in order to achieve BPI management should streamline its activities, adopt new technologies and develop employees' skills and performance. When it comes to BPI and the adoption of technology, there is a need to take extra measures in order to guarantee the ability of an organization to interact with the technological processes and activities in a smoother way. Here appears the role of BPI in helping to embrace technological adoption in an organization and pave the way for a smoother change management as in the case of e-government.

\subsection{Business Architecture}

The concept of business architecture of BA refers to the formal description of the way an organization employs its competences in order to achieve its goals and aims based on its strategic plans and objectives (Missah, 2015). Callegård and Händling (2011) on the other hand saw that BA is the gathering of business concepts which in total formulates the ideas of constructive, operative and decorative streams which in its turn can deliver the business to the state of full ability to achieve its objectives if followed $\mathrm{n}$ a good coherent approach. Møller (2007) also added that looking at business architecture is more like looking at departments, processes and images of an organization that are in all formulates the overall image of an organization. Business architecture is important in the field of e-government. The description of an organization manifests the role of each department in helping the smooth transition from conventional methods to electronic ones leading to more coherent process of adoption and better end results (Fjeldstad \& Snow, 2018).

\subsection{Risk Management}

Risk management is a process of measuring and assessing risks and developing strategies for managing them. These strategies include transferring risks, avoiding them, minimizing their negative impacts, accepting some or all of their consequences, and preparing plans to deal with risks that must occur (Kuczmarski, 2000). It can also be defined as an administrative activity that aims to control risks and reduce them to acceptable levels. More precisely, it is the process of identifying, measuring, controlling and reducing the risks faced by a company, organization or project (Craig \& Edbury, 2015). Risk management is one of the most influential factors that have the ability to influence the streamlining of e-government projects. There is deep need to build the whole projects on bases that gathers between excellence and risk management in order to protect the project from any cyber-attacks especially with the increasing fragility of the network encompassing the ongoing developments of human skills in the field of hacking and decoding (Dillerup et al., 2018). Risk management must be integrated with the corporate culture and with effective policy and programs of senior management. Risk management should translate strategies into practical and tactical goals and assign responsibilities across the organization to each manager and risk management officer as part of their job description (Ma Prieto and Pilar Perez-Santana, 2014).

\subsection{Skills and Experiences}

Skills and experiences are very important when it comes to managing an organization in an innovative approach. As a start, employees must be more aware of what innovation means and how innovation can be a part of the managerial process (Cingula et al., 2013). They must be aware of what an innovative management aims at and how to deal with a management that is seeking to be innovative. Bollinger (2019) stated that in order to support innovative management employees must be innovative themselves; author argues that one can't deal in logic with a person who lacks mental stability and the same goes in eh dilemma of being innovative as a management (Chung et al., 2008).

\subsection{Innovative Management}

As organizations and institutions have become complex and intertwined with a lot of administrative uncertainty, innovative management became a requirement to raise the mission of the organization and bring it to good performance (Lazzarotti et al., 2017). The culture of the organization or institution is no less important than the availability of financial resources and technological capabilities of the institution. The movement of the organization is an innovative management that accommodates the variables of the times and is familiar with the modern methods of innovative management, which need to be applied 
in organizations' basic requirements, to contribute to improve the quality of administrative and internal processes work (Muzamil Naqshbandi and Kaur, 2014). There are a number of administrative requirements that must be met in the regulatory environment of innovative management, summarized in the following as according to (Salehi et al., 2018):

- Support and commitment of senior management.

- $\quad$ Reformulate the administrative strategy of organizations.

- Good planning with clear objectives, standards, and measurable results.

- Harmonization of business process re-activities with business objectives.

- $\quad$ Adopting an institutional system based on power sharing and decision-making.

As for the obstacles of adopting managerial innovation Shang et al., (2010) argued that among the obstacles that hinders the adoption of managerial innovation is the idea of top management not being convinced of the importance of change so it won't encourage new creative ideas. On the other hand, McIntyre-Bhatty et al. (2014) stated that the acceptance of stereotypes and traditional management might hinder the adoption of innovative management in addition to the absence of an annual plan by the organization. José Rodríguez and Guzmán (2013) saw that managerial innovation might be a dream for those organizations which belief in the methods of central management, bureaucracy and rigid administrative in addition to the difficulty of amendment of regulations and regulations, and fear of the risks and consequences of amendment.

\section{Methods}

Current study depended on quantitative approach in gathering data in order to realize hypotheses and answer study questions. The quantitative approach generated numerical figures which had the ability to explain the trends among study sample and highlight their orientation in reference to study questionnaire. A questionnaire was developed to be study tool which consisted of two main sections the first took into perspective the demographic variables of sample while the second section presented the sample's attitude towards statements of questionnaire. Population of study consisted of IT department managers, IT officers and technicians who work within the field of IT implementation within the e-government project in Jordan. A sample of (150) individuals was chosen to represent current study through being exposed to the questionnaire. After the application and distribution process of the questionnaire, total of (123) individuals responded which gave of response rate of (82\%) as statistically accepted.

\subsection{Analysis}

Following section presented analysis of study tool as according to respondents' answers to the questionnaire. The first section presented results of sample's demographics distribution:

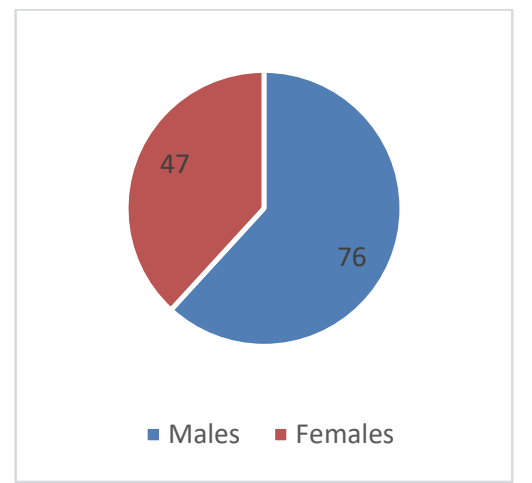

Gender

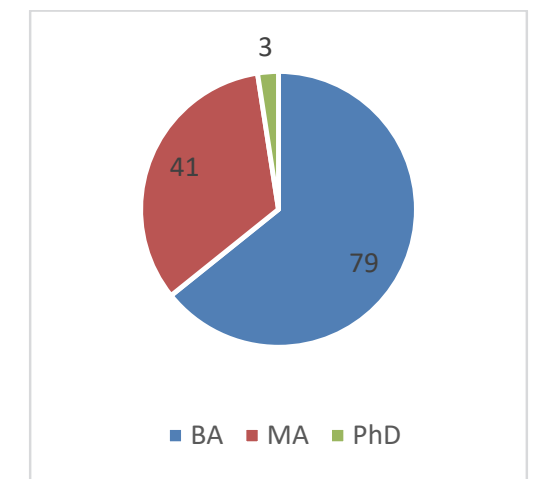

Educational background

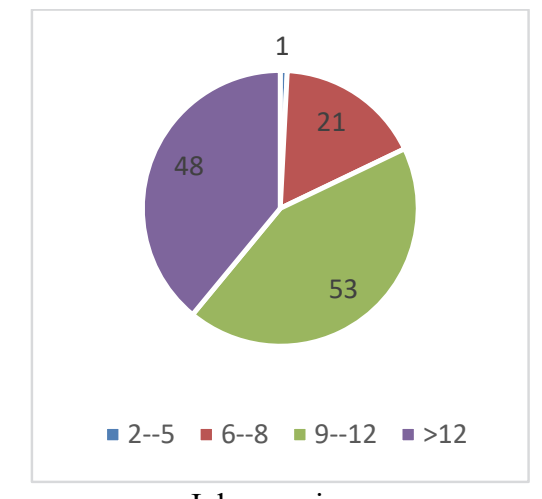

Job experience

Fig. 2. Personal characteristics of the participants

According to Fig. 2, it can be seen that respondents' demographics of questionnaire ranged between gender, experience and education. According to the table, it appeared that majority of the sample was male individuals forming $61.8 \%$ of the total sample compared to females who formed $38.2 \%$ of the total sample. As for the educational qualification, it appeared through the analysis in Fig. 2 above that the majority of sample formed $64.2 \%$ had BA degree while $33.3 \%$ had master's degree compared to $\mathrm{PhD}$ holders who appeared to form only $2.4 \%$ of the sample. In reference to experience in the field, it appeared that individuals who had an experience of $9-12$ years formed $43.1 \%$ of the sample and that explains why the majority had the BA degree not higher, the idea revolved around the fact that individuals seemed to be more interactive with the project of egovernment which gave them the experience they needed that is practical in its nature more than theoretical. Table 1 highlights individuals' attitude towards statements of questionnaire which formed the overall understanding of variables. It appeared through results of mean and standard deviation that individuals had a positive attitude towards statements of questionnaire as their mean was above the mean of the scale 3.00. This is seen to be a good indicator that individuals had the needed awareness of what statement referred to as they managed to give and indicate a direct answer to it. 
Table 1

Questionnaire analysis

\begin{tabular}{|c|c|c|c|c|c|}
\hline \multicolumn{6}{|l|}{ Descriptive Statistics } \\
\hline & $\mathrm{N}$ & $\min$ & $\max$ & Mean & Std. Dev. \\
\hline \multicolumn{6}{|l|}{ Business Process Improvement } \\
\hline Managers always analyze business procedures inside the organization & 123 & 1 & 5 & 3.75 & 1.106 \\
\hline Through business process improvements managers can go beyond standards & 123 & 1 & 5 & 3.76 & 1.345 \\
\hline BPI identifies the operations or employee skills that could be improved to encourage smoother procedures & 123 & 1 & 5 & 4.04 & 1.035 \\
\hline \multicolumn{6}{|l|}{$\begin{array}{l}\text { Business Architecture } \\
\text { B }\end{array}$} \\
\hline Infrastructure of technology is important to guarantee the best managerial innovation & 123 & 1 & 5 & 4.33 & .911 \\
\hline $\begin{array}{l}\text { There is a need to support the organization with the needed technological infrastructure to support decision } \\
\text { making }\end{array}$ & 123 & 1 & 5 & 3.96 & 1.027 \\
\hline Organizational culture must be ready to embrace technology & 123 & 1 & 5 & 3.80 & 1.000 \\
\hline \multicolumn{6}{|l|}{ Risk Management } \\
\hline Risk management strategies is important to avoid sudden malfunctions & 123 & 1 & 5 & 4.05 & .974 \\
\hline With risk-protected environment; managerial innovative ideas can be more approachable. & 123 & 2 & 5 & 4.10 & .891 \\
\hline Risk management can predict possible risks and dangers that might be harmful for innovation & 123 & 1 & 5 & 3.11 & 1.260 \\
\hline \multicolumn{6}{|l|}{ Skills and Experiences } \\
\hline Individuals must be skilled to practice innovative managerial activities & 123 & 1 & 5 & 3.83 & 1.335 \\
\hline Management must train its employees to understand managerial innovation through technology & 123 & 1 & 5 & 4.38 & .963 \\
\hline Technology must be a part of skilled staff in order to achieve results & 123 & 2 & 5 & 4.18 & .915 \\
\hline \multicolumn{6}{|l|}{ Managerial Innovation } \\
\hline Managerial innovation lies at the operational level, not at the theoretical level of management. & 123 & 1 & 5 & 4.19 & .970 \\
\hline Managerial innovation include the 'intentional' aiming to extend the organization's objectives & 123 & 1 & 5 & 3.36 & 1.294 \\
\hline $\begin{array}{l}\text { Managerial innovation changes how managers seek to achieve the objectives of the company mainly } \\
\text { through the introduction of new management practices to improve business performance }\end{array}$ & 123 & 1 & 5 & 3.71 & .990 \\
\hline $\begin{array}{l}\text { Managerial innovation is recursive and non-linear process consisting of four phases: motivation, invention, } \\
\text { implementation and theorizing and labeling }\end{array}$ & 123 & 1 & 5 & 3.92 & .911 \\
\hline Managerial innovation concerns a practice, process, structure or technique & 123 & 1 & 5 & 3.82 & .869 \\
\hline Valid N (listwise) & 123 & & & & \\
\hline
\end{tabular}

In examining the analysis of variables' influence; the following table highlighted that respondents had the needed awareness regarding the presented variables due to its ability to score higher the mean of the scale and referred to the variables as good indicators.

Table 2

Descriptive statistics

\begin{tabular}{|c|c|c|c|c|c|}
\hline & $\mathrm{N}$ & Minimum & Maximum & Mean & Std. Deviation \\
\hline Improvement & 123 & 1.25 & 5.00 & 3.8780 & .88381 \\
\hline Architecture & 123 & 1.33 & 5.00 & 4.0298 & .77178 \\
\hline Risk & 123 & 2.00 & 5.00 & 3.7507 & .68365 \\
\hline Skills & 123 & 2.67 & 5.00 & 4.1301 & .67702 \\
\hline Innovation & 123 & 1.00 & 5.00 & 3.7984 & .72812 \\
\hline
\end{tabular}

\subsection{Reliability Test}

A Cronbach's' alpha test was used to test the reliability of the questionnaire. It is found that a value of $(0.866)$ for the all items is greater than accepted percent 0.60 .

\subsection{Collinearity statistics test}

Multicollinearity between the independent variables is checked using the Collinearity statistics: Tolerance and Variance Inflation Factor (VIF). The minimum acceptable cutoff value for tolerance is typically (0.10). The maximum acceptable cutoff value for the VIF is (10). In other words, to indicate no problem with multicollinearity tolerance value should not be less than (0.10) while VIF value should not be more than (10) (Belsley et al., 2005).

Table 3

Collinearity statistics

\begin{tabular}{|c|c|c|c|c|c|}
\hline \multirow[b]{2}{*}{ Variable } & \multicolumn{2}{|c|}{ Collinearity Statistics } & \multirow[b]{2}{*}{ Variable } & \multicolumn{2}{|c|}{ Collinearity Statistics } \\
\hline & Tolerance & VIF & & Tolerance & VIF \\
\hline Improvement & .425 & 2.351 & Risk & .776 & 1.288 \\
\hline Architecture & .372 & 2.687 & Skills & .841 & 1.189 \\
\hline
\end{tabular}

As we see in Table 3, VIF values for each independent variable is less than 10, with tolerance ranges between (0.231-0.297). This means that there is no occurrence for any multicollinearity problem between the independent variables.

\subsection{Main Hypothesis}

ITMG positively influence managerial innovation within e-government project in Jordan. 
Table 4

The summary of testing the main hypothesis

\begin{tabular}{|c|c|c|c|c|c|c|c|}
\hline \multirow[t]{2}{*}{ Model } & & \multicolumn{2}{|c|}{ Unstandardized Coefficients } & \multirow{2}{*}{$\begin{array}{c}\text { Standardized Coefficients } \\
\text { Beta }\end{array}$} & \multirow[t]{2}{*}{$\mathrm{t}$} & \multirow[t]{2}{*}{ Sig. } & \multirow{2}{*}{$\begin{array}{c}\text { Collinearity Statistics } \\
\text { Tolerance }\end{array}$} \\
\hline & & $\mathrm{B}$ & Std. Error & & & & \\
\hline \multirow[t]{5}{*}{1} & (Constant) & -.006 & .358 & & -.017 & .986 & \\
\hline & Improvement & .066 & .079 & .080 & .825 & .411 & .425 \\
\hline & Architecture & .363 & .097 & .385 & 3.732 & .000 & .372 \\
\hline & Risk & .279 & .076 & .262 & 3.674 & .000 & .776 \\
\hline & Skills & .252 & .074 & .234 & 3.409 & .001 & .841 \\
\hline
\end{tabular}

F-value $=33.666($ Sig. $=0.000)$ Adjusted R-Square $=0.517$ Durbin-Watson $=1.567$

Multiple regression was used to test the main hypothesis, with the $\mathrm{r}$ value of 0.73 , it was seen that independent variables and dependent variables were strongly correlated and with an F value of 33.666 at 0.05 significant at (0.05), it was confirmed that ITMG influences managerial innovation within e-government project in Jordan.

\subsubsection{Sub-Hypotheses}

First sub-hypothesis: The role of business process improvement on managerial innovation

The first hypothesis of the survey investigates the role of Business Process Improvement on managerial innovation within egovernment project in Jordan. Table 5 demonstrates the results of simple regression technique for testing this hypothesis.

Table 5

The summary of testing the first sub-hypothesis

\begin{tabular}{|c|c|c|c|c|c|c|}
\hline \multirow[t]{2}{*}{ Model } & & \multicolumn{2}{|c|}{ Unstandardized Coefficients } & \multirow{2}{*}{$\begin{array}{c}\text { Standardized Coefficients } \\
\text { Beta }\end{array}$} & \multirow[t]{2}{*}{$\mathrm{t}$} & \multirow[t]{2}{*}{ Sig. } \\
\hline & & $\mathrm{B}$ & Std. Error & & & \\
\hline 1 & (Constant) & 2.056 & .250 & & 8.235 & .000 \\
\hline 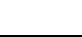 & Improvement & .449 & .063 & .545 & 7.159 & .000 \\
\hline
\end{tabular}

Depending on Linear regression, an $r$ value of 0.545 appeared and confirmed that independent variable and dependent variable are moderately correlated. F value of 7.159 and was significant at 0.05 which confirmed that Business Process Improvement influence managerial innovation within e-government project in Jordan.

Second sub-hypothesis: The role of business architecture on managerial innovation

The second sub-hypothesis also investigate the role of Business Architecture on managerial innovation within e-government project in Jordan. Table 6 shows the results of our survey.

Table 6

The summary of testing the second sub-hypothesis

\begin{tabular}{llcccc}
\hline \multirow{2}{*}{ Model } & & \multicolumn{2}{c}{ Unstandardized Coefficients } & \multicolumn{2}{c}{ Standardized Coefficients } \\
\cline { 2 - 5 } 1 & Sig. & Std. Error & Beta & \\
& (Constant) & 1.303 & .265 & .000 & \\
& Architecture & .619 & .065 & .656 & 9.908 \\
\hline
\end{tabular}

F-value $=91.635($ Sig. $=0.000)$ Adjusted R-Square $=0.426$

$2^{\text {nd }}$ hypothesis was tested using linear regression. With the $\mathrm{r}$ value of 0.545 , it was confirmed that independent variable and dependent variable are strongly correlated. A $T$ value of 9.573 and was 0.05 significant at (0.05) confirmed that Business Architecture influence managerial innovation within e-government project in Jordan.

Third sub-hypothesis: The role of risk management on managerial innovation

The third hypothesis of this survey studies the role of risk management on managerial innovation. Table 7 presents the results of testing the hypothesis based on simple regression method.

Table 7

The results of testing the third sub-hypothesis

\begin{tabular}{llrrrr}
\hline \multirow{2}{*}{ Model } & & \multicolumn{2}{c}{ Unstandardized Coefficients } & \multicolumn{2}{c}{ Standardized Coefficients } \\
\cline { 2 - 5 } 1 & B & Std. Error & \multicolumn{2}{c}{ Beta } \\
\cline { 2 - 5 } & (Constant) & 1.780 & .319 & .084 & .000 \\
\hline
\end{tabular}

F-value $=41.476($ Sig. $=0.000)$ Adjusted R-Square $=0.249$

This hypothesis was tested using linear regression analysis. With the $\mathrm{r}$ value of 0.505 , it was confirmed that independent variable and dependent variable are moderately correlated. Again, with 6.44 as the value of $t$ at 0.05 significant at (0.05), it is confirmed that Risk Management influence managerial innovation within e-government project in Jordan. 
The last sub-hypothesis investigates the role of skills and experience on managerial innovation. Table 8 shows the results of our survey.

Table 8

The results of testing the fourth hypothesis

\begin{tabular}{|c|c|c|c|c|c|c|}
\hline & \multirow[t]{2}{*}{ Model } & \multicolumn{2}{|c|}{ Unstandardized Coefficients } & \multirow{2}{*}{$\begin{array}{c}\text { Standardized Coefficients } \\
\text { Beta }\end{array}$} & \multirow[t]{2}{*}{$\mathrm{t}$} & \multirow[t]{2}{*}{ Sig. } \\
\hline \multirow{3}{*}{1} & & $\mathrm{~B}$ & Std. Error & & & \\
\hline & (Constant) & 1.817 & .366 & & 4.962 & .000 \\
\hline & Skills & .480 & .088 & .446 & 5.482 & .000 \\
\hline
\end{tabular}

F-value $=30.056($ Sig. $=0.000)$ Adjusted R-Square $=0.19$

This hypothesis was tested using linear regression analysis. With the $r$ value of 0.446 , it was confirmed that independent variable and dependent variable are moderately correlated. Again, with 5.482 as the value of $t$ at 0.05 significant at (0.05), it is confirmed that Skills and Experiences influence managerial innovation within e-government project in Jordan.

\section{Discussion and Conclusion}

Current study aimed at examining the influence of ITMG and its requirements on managerial innovation within the project of e-government in Jordan. A questionnaire was distributed on (123) IT head departments, officers and technicians in Jordanian E-government project. Results of study indicated an influence of ITMG requirements in achieving the best results of innovative management through paving the way for more influential managerial innovation this appeared through the $\mathrm{R}$ value of 0.730 referring to the relationship between dependent and independent variables. Among the taken variable of study (business process improvement, business architecture, risk management, and skills and experiences) it appeared that the most influential variable on managerial innovation of ITMG requirements was business architecture which scored and R value of 0.565 referring to the architecture of the organization as influential. This result rhymed with what Ma (2018) referring to the influence of ITMG in developing the innovative orientation in an organization towards being more innovative in its thinking streams. Also, Arciénaga Morales et al. (2018) agreed with the same results referring that taking extra attention to the IT requirements and managing their applications within an organization can help in giving the management an approach to be more innovative in taking decisions due to its ability to employ new and state of the art ideas and examine its influence on reality. In the $2^{\text {nd }}$ rank, there appeared an influence of risk management with an $\mathrm{R}$ value of 0.505 referring to the adoption of risk management strategies as influential in supporting managerial innovation. Huizingh (2011) agreed on the fact that when an organization especially a governmental party - adopts a solid risk management strategy; it would help in driving the focus of the management towards being more innovative in the managerial approach and create more up-to-date model of management that would help promote their project. In eh case of e-government; the fact that the management feeling protected from risks was seen to be the first and most provocative approach towards being more innovative. The rest of the variable including (BPI and Skills and experiences) which scored an $\mathrm{R}$ value of .545 and 0.446 respectively; it proved its influences in supporting the organizational seeking to employ managerial innovation in order to create more homogenous managerial stream and increase the influence of ITMG on managerial activities. In conclusion, and as according to the results presented earlier, it can't be denied that information technology management can have a positive influence on the project of e-government given its sensitivity as a public sector. The reason for the need of managerial innovation is attributed to the fact that e-government is a project that presents civil services to individuals. It helps in managing their daily needs and requirements in accordance to the law, this is one of the sensitive activities that e-government is obliged to do and it has to be always ready to serve individuals with the best results possible. Based on results, discussion and conclusion of study the following recommendation are to be put under consideration:

- E-government controllers must have extra attention towards adopting the suitable BIP in order to guarantee the best results of application in terms of service quality, time and satisfaction.

- Business architecture are among the aspects that are most important to the internal processes of the organization so it and be managed on a lower level of attention compared to the external levels like IT and networks.

- Training courses, workshops and team work is one of the ideas that must be applied within the project of e-government in Jordan as it was revealed based on the questionnaire and launching from previous studies that there is a lack in the training plans for employees to be a part of such nationwide projects.

\section{References}

Adesola, S., \& Baines, T. (2005). Developing and evaluating a methodology for business process improvement. Business Process Management Journal, 11(1), 37-46.

Al-Athmay, A. A. A., Fantazy, K., \& Kumar, V. (2016). E-government adoption and user's satisfaction: an empirical investigation. EuroMed Journal of Business, 11(1), 57-83.

Arciénaga Morales, A., Nielsen, J., Bacarini, H., Martinelli, S., Kofuji, S., \& García Díaz, J. (2018). Technology and innovation management in higher education - Cases from Latin America and Europe. Administrative Sciences, 8(2), 11.

Azam, M. S. (2015). Diffusion of ICT and SME performance. In E-Services Adoption: Processes by Firms in Developing Nations (pp. $7-$ 290). Emerald Group Publishing Limited. 
Belsley, D. A., Kuh, E., \& Welsch, R. E. (2005). Regression Diagnostics: Identifying Influential Data and Sources of Collinearity (Vol. 571). John Wiley and Sons.

Bollinger, S. R. (2019). Creativity and forms of managerial control in innovation processes: tools, viewpoints and practices. European Journal of Innovation Management.

Brynjolfsson, E., \& Hitt, L. M. (2000). Beyond computation: Information technology, organizational transformation and business performance. Journal of Economic perspectives, 14(4), 23-48.

Butt, N., Warraich, N. F., \&Tahira, M. (2019). Development level of electronic government services: An empirical study of e-government websites in Pakistan. Global Knowledge, Memory and Communication, 68(1/2), 33-46.

Callegård, C., \&Händling, M. (2011). Enterprise Architecture: How does it support innovation?.

Chung, Y. C., Hsu, Y. W., Chiu, C. C., Chen, C. P., \& Tsai, C. H. (2008). An empirical study on the correlation among innovative strategies, motivation, level of implementing innovative activities and business performance in Taiwan' high-tech manufacturers. Asian Journal on Quality, 9(3), 93-112.

Cingula, M., Nedelko, Z., \&Potocan, V. (2013). The role of management innovativeness in modern organizations. Journal of Enterprising Communities: People and Places in the Global Economy.

Craig, C., \& Edbury, M. (2015). Innovation: Management risk, not avoiding it. Future Directions for Scientific Advance, 163.

Dahiya, D., \& Mathew, S. K. (2016). IT assets, IT infrastructure performance and IT capability: a framework for e-government. Transforming Government: People, Process and Policy, 10(3), 411-433.

Dillerup, R., Kappler, D., \& Oster, F. (2018). Improving the management of innovation risks-R\&D risk assessment for large technology projects. Journal of Management and Strategy, 9(1), 31-52.

Fjeldstad, Ø. D., \& Snow, C. C. (2018). Business models and organization design. Long Range Planning, 51(1), 32-39.

Florkowski, G. W. (2018). HR Technology Systems: An Evidence-Based Approach to Construct Measurement. In Research in Personnel and Human Resources Management (pp. 197-239). Emerald Publishing Limited.

Hamidi, S., \& Benabdeljlil, N. (2015). Managerial and Technological Innovations: Any Relationship?. Procedia-Social and Behavioral Sciences, 181, 286-292.

Hassan, M. H., \& Lee, J. (2019). Policymakers' perspective about e-Government success using AHP approach: Policy implications towards entrenching Good Governance in Pakistan. Transforming Government: People, Process and Policy, 13(1), 93-118.

Huizingh, E. K. (2011). Open innovation: State of the art and future perspectives. Technovation, 31(1), 2-9.

José Rodríguez, M., \& Guzmán, C. (2013). Innovation in social economy firms. Management Decision, 51(5), 986-998.

Kane, G. C., \&Alavi, M. (2007). Information technology and organizational learning: An investigation of exploration and exploitation processes. Organization Science, 18(5), 796-812.

Kuczmarski, T. D. (2000). Measuring your return on innovation. Marketing Management, 9(1), 24.

Lazzarotti, V., Bengtsson, L., Manzini, R., Pellegrini, L., \&Rippa, P. (2017). Openness and innovation performance: an empirical analysis of openness determinants and performance mediators. European Journal of Innovation Management, 20(3), 463-492.

Ma Prieto, I., \& Pilar Perez-Santana, M. (2014). Managing innovative work behavior: the role of human resource practices. Personnel Review, 43(2), 184-208.

Ma, Y. (2018, February). Research on Technology Innovation Management in Big Data Environment. In IOP Conference Series: Earth and Environmental Science (Vol. 113, No. 1, p. 012141). IOP Publishing.

McIntyre-Bhatty, T., Weiwei, W., Chen, H., Liu, H., \& Cheung, H. (2014). Radical innovation, market forces, political and business relationships. Chinese Management Studies.

Melville, N., Kraemer, K., \&Gurbaxani, V. (2004). Information technology and organizational performance: An integrative model of IT business value. MIS quarterly, 28(2), 283-322.

Missah, Y. M. (2015). Business Innovation with Enterprise Architecture. International Journal of Computer Applications, 120(9).

Møller, C. (2007). Process innovation laboratory: a new approach to business process innovation based on enterprise information systems. Enterprise Information Systems, 1(1), 113-128.

Mousavi, S. S., \&HabibyBadrAbady, M. (2008). The role of information technology in organizational procedures' improvement with knowledge based approach-a study of the Iranian taxation affairs organization. World Applied Sciences Journal, 3(2), 55-66.

Muzamil Naqshbandi, M., \& Kaur, S. (2014). Do managerial ties support or stifle open innovation?. Industrial Management \& Data Systems, 114(4), 652-675.

Saatçioğlu, Ö. Y., Deveci, D. A., \&GüldemCerit, A. (2009). Logistics and transportation information systems in Turkey: e-government perspectives. Transforming Government: People, Process and Policy, 3(2), 144-162.

Salehi, M., DashtBayaz, M. L., \&Mohammadi Moghadam, S. (2018). The relationship between management characteristics and firm innovation. International Journal of Productivity and Performance Management, 67(7), 1113-1131.

Shang, H., Huang, P., \& Guo, Y. (2010). Managerial cognition: the sources of sustainable competitive advantage in hypercompetition: A case study. Nankai Business Review International, 1(4), 444-459.

Siha, S. M., \& Saad, G. H. (2008). Business process improvement: empirical assessment and extensions. Business Process Management Journal, 14(6), 778-802.

Swanepoel, M., Du Toit, A., \& Van Brakel, P. A. (2001, August). Management of information technology in academic information services. In ASLIB proceedings (Vol. 53, No. 6, pp. 224-237). MCB UP Ltd.

Zellner, G. (2011). A structured evaluation of business process improvement approaches. Business Process Management Journal, 17(2), 203-237.

Zhao, F., Wallis, J., \& Singh, M. (2015). E-government development and the digital economy: a reciprocal relationship. Internet Research, 25(5), 734-766.

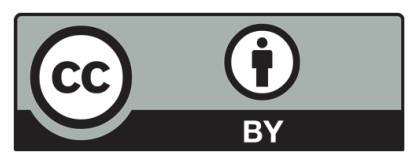

(C) 2020 by the authors; licensee Growing Science, Canada. This is an open access article distributed under the terms and conditions of the Creative Commons Attribution (CC-BY) license (http://creativecommons.org/licenses/by/4.0/). 